Jurnal Caraka Prabu Vol.5 No. 1 Juni 2021

\title{
INOVASI PELAYANAN PUBLIK DINAS KEPENDUDUKAN DAN CATATAN SIPIL DI KOTA BANDUNG
}

\author{
Rianandita 'Arsy Elkesaki1), Riska Dwi Oktaviani2), Melina Putri \\ Setyaherlambang ${ }^{3}$ \\ Ilmu Pemerintahan, Fakultas Ilmu Sosial dan Politik, Universitas \\ Muhammadiyah Yogyakarta, Indonesia
}

\begin{abstract}
ABSTRAK
Pelayanan publik merupakan suatu kinerja yang dilakukan oleh pemerintah bagi masyarakat. Pelayanan publik bertujuan untuk membentuk suatu kenyamanan bagi kedua belah pihak. Tulisan ini akan membahas mengenai berbagai jenis inovasi pelayanan publik di Dinas Kependudukan dan Catatan Sipil Kota Bandung. Penerapan inovasi pelayanan publik oleh Dinas Kependudukan dan Pencatatan Sipil Kota Bandung seperti e-SPASI, Kartu Identitas Anak, e-PunTEN, Mepeling dan Delivery Service. Penelitian ini menggunakan metode kualitatif berupa pengumpulan data dari internet yang mana untuk mendeskripsikan bagaimana inovasi yang dikembangkan dari perkembangan pelayanan publik di Dinas Kependudukan dan Catatan Sipil Kota Bandung. Penelitian ini bertujuan untuk mengetahui bagaimana jenis inovasi pelayanan publik di Dinas Kependudukan dan Catatan Sipil Kota Bandung. Temuan penelitian menunjukkan bahwa semakin berkembangnya teknologi di masyarakat maka dalam suatu pelayanan publik pun harus diikuti dengan perkembangan teknologi. Dengan adanya berbagai inovasi ini diharapkan Dinas Kependudukan dan Pencatatan Sipil Kota Bandung dapat melayani masyarakat Kota Bandung dengan baik.

Kata kunci: inovasi, pelayanan publik, Dinas Kependudukan dan Catatan Sipil
\end{abstract}

\begin{abstract}
Public service is a performance performed by the government for the community. Public services aim to create comfort for both parties. This paper will discuss various types of public service innovations at the Bandung City Civil Registry. The application of public service innovations by the Department of Population and Civil Registration of the City of Bandung such as e-SPASI, Children's Identity Cards, e-PunTEN, Mepeling and Delivery Service. This study uses a qualitative method in the form of data from the internet which is to describe how the innovations developed from the development of public services in the Department of Population and Civil Registry of Bandung City. This study aims to see how the types of public service innovations in the Department of Population and Civil Registry of Bandung City. The research findings show that the more technology develops in society, the more public services must be followed by technological developments. With these various innovations, it is hoped that the Department of Population and Civil Registration of the City of Bandung can serve the people of Bandung City well.
\end{abstract}


Jurnal Caraka Prabu Vol.5 No. 1 Juni 2021

Keywords: innovation, public services, Population and Civil Registry Service

\section{PENDAHULUAN}

Dinas Kependudukan dan Pencatatan Sipil merupakan suatu instansi pemerintahan yang bergerak dalam bidang pelayanan publik. Pelayanan publik yang dilakukan diantaranya terkait dengan kepengurusan Kartu Tanda Penduduk (KTP), Kartu Keluarga (KK), Akta Kelahiran, hingga Surat Kematian. Pelayanan publik yang prima tentunya selalu diharapkan oleh masyarakat, meskipun tuntutan tersebut pada kenyataannya sering tidak sesuai dengan yang diharapkan. Pelayanan publik yang dilakukan oleh pemerintah masih cenderung berbelit-belit, mahal, serta kurang efektif dan efisien. Keadaan tersebut terjadi karena masih memposisikan masyarakat sebagai pihak yang melayani bukan yang dilayani. Oleh karena itu, perlu dilakukan reformasi pelayanan publik dengan mengembalikan dan mendudukkan "pelayan" dan yang "dilayani" ke pengertian yang sesungguhnya. Meskipun berdirinya suatu negara sesungguhnya untuk kepentingan masyarakat, namun pelayanan yang seharusnya ditujukan kepada masyarakat dibalik menjadi pelayanan masyarakat terhadap negara (Hisbani, Karim, dan Malik, 2015).

Pelayanan publik merupakan suatu hal yang bermanfaat bagi masyarakat di setiap negara atau dapat juga diartikan sebagai sebuah pelayanan kepada konsumen yang tujuannya untuk memenuhi kebutuhan konsumen tersebut. Di dalam studi Ilmu Pemerintahan, maka yang menjadi pelayan adalah pemerintah dan konsumen adalah masyarakat. Agar terbentuk suatu kenyamanan bagi kedua belah pihak maka masyarakat harus mendominasi kondisi yang ada di daerahnya. Dengan adanya kondisi yang pelayanan publik yang kurang baik di suatu daerah maka pemerintah sebagai pelayan dapat memberikan pelayanannya sesuai dengan peran atau tugas yang mereka patuhi. Sebagai implementasi UndangUndang Nomor 25 Tahun 2009 pasal 7 
ayat (4) huruf c, tentang pelayanan publik, maka ditetapkan pada tahun 2014 sebagai tahun inovasi pelayanan publik sebagai upaya memfokuskan kebijakan dan implementasi kebijakan terarah, mendalam dan berkesinambungan dalam membangun inovasi pelayanan publik di lingkungan kementerian/ lembaga/ pemerintah daerah yang diharapkan akan mendorong percepatan pelaksanaan reformasi birokrasi.

Kualitas pelayanan publik yang baik dari aparatur pemerintah, dibuat didalam Keputusan Menteri Pendayagunaan Aparatur Negara Nomor 63/KEP/M.PAN/7/2003 tentang pedoman umum penyelenggaraan pelayanan publik. Kebijakan ini berguna untuk meningkatkan kualitas dalam pelayanan publik. Namun kebijakan ini tidak akan berjalan maksimal jika aparaturnya tidak bekerja secara optimal karena permasalahan ini harus dilakukan secara konsisten dengan memperhatikan apa yang sedang diperlukan oleh masyarakat dan yang akan memudahkan masyarakat dalam proses kehidupan sehari-hari. (Haqie, Nadiah, \& Ariyani, 2020).

Pelayanan publik harus berkembang seiring berjalannya waktu, maka dari itu pelayanan publik membutuhkan suatu inovasi (Jati, 2011). Di zaman milenial seperti sekarang ini, perkembangan teknologi makin merambat ke seluruh dunia, sehingga makin banyak masyarakat yang menggunakan teknologi untuk kehidupan sehari-harinya. Dengan adanya kemajuan teknologi, maka pelayanan publik juga harus memiliki inovasi baru yang berhubungan dengan teknologi (Nasikhah, 2019).

Istilah inovasi sudah tidak asing lagi dalam segala aspek kehidupan, merupakan salah satu faktor yang berperan penting dalam menghadapi dan mengatasi berbagai masalah yang melibatkan individu, masyarakat, organisasi, dan negara. Dalam konteks hubungan negara dan publik, negara berperan sebagai aktor fasilitator dan regulator kebijakan public dan inovasi sebagai kata kunci strategis ketika output dan hasil kebijakan tidak dapat memenuhi kebutuhan dan dinamika 
perkembangan masyarakat yang semakin global. Menurut Damanpour (2008), menyatakan bahwa pelayanan inovasi dapat berupa produk atau jasa yang baru, teknologi baru, teknologi proses produksi yang baru, sistem struktur dan administrasi baru atau rencana baru untuk anggota organisasi. Inovasi pelayanan publik merupakan suatu keharusan bagi pemerintah pusat maupun pemerintah daerah guna untuk mengimplementasikan pelaksanaan desentralisasi yaitu mengupayakan peningkatan kesejahteraan, kemakmuran dan kemandirian bagi masyarakat dan daerahnya (Yanuar, 2019).

Inovasi memiliki atribut inovasi dalam implementasinya, yaitu relative advantage atau keuntungan relatif. Dibandingkan dengan inovasi sebelumnya, inovasi harus memiliki keunggulan dan nilai lebih. Selalu ada nilai kebaruan dalam inovasi, yang menjadi ciri khas yang membedakannya dari yang lain, compability atau kesesuaian. Inovasi juga memiliki sifat kebalikan dari kompatibel atau kesesuaian dengan inovasi yang diganti. Tujuannya agar tidak hanya membuang inovasi lama, selain karena biaya yang sedikit, tetapi juga memanfaatkan inovasi lama sebagai bagian dari proses transisi ke inovasi baru. Selain itu, dapat mendorong proses adaptasi dan pembelajaran inovatif dengan cara yang lebih cepat, complexity atau kerumitan. Dibandingkan dengan inovasi sebelumnya, inovasi memiliki sifat baru dan kompleksitas yang lebih tinggi. Namun, karena inovasi menyediakan metode yang lebih baru dan lebih baik, tingkat kerumitan ini biasanya bukan merupakan masalah penting, triability atau kemungkinan dicoba. Setelah diuji dan dibuktikan memiliki keunggulan atau nilai lebih dari inovasi lama barulah inovasi tersebut dapat diterima. Oleh karena itu, produk inovasi harus lulus tahap pengujian publik, dan setiap orang atau masingmasing pihak memiliki kesempatan untuk menguji kualitas, ketelitian atau kemudahan pengamatan dari inovasi tersebut. Sebuah inovasi 
harus dapat diamati dalam hal cara kerjanya dan menghasilkan hal-hal yang lebih baik. (Hisbani, Karim, dan Malik: 2015)

Dalam penelitian ini, kami membahas mengenai inovasi pelayanan publik di Dinas Kependudukan dan Catatan Sipil Kota Bandung. Dinas Kependudukan dan Catatan Sipil Kota Bandung merupakan kantor utama Dinas Kependudukan dan Catatan Sipil Kota Bandung yang melayani seluruh warga Kota Bandung dimana semua pelayanan (kecuali pelayanan legalisir dan pelayanan informasi pengaduan). Terdapat berbagai jenis inovasi yang dilaksanakan oleh Dinas Kependudukan dan Catatan Sipil Kota Bandung yang sudah berlangsung dari tahun 2016.

\section{METODE PENELITIAN}

Metode penelitian ini menggunakan jenis penelitian deskriptif dengan pendekatan kualitatif yang mana untuk mendeskripsikan bagaimana inovasi yang dikembangkan dari perkembangan pelayanan publik di Dinas Kependudukan dan Catatan Sipil Kota Bandung. Pendekatan kualitatif adalah melakukan analisis deskriptif terhadap data dan hasil pengamatan. Model analisis data dalam penelitian ini mengikuti konsep yang diberikan Miles and Huberman. Miles and Hubermen mengungkapkan bahwa aktifitas dalam analisis data kualitatif dilakukan secara interaktif dan berlangsung secara terusmenerus pada setiap tahapan penelitian sehinggasampai tuntas (Fikri, Sholeh, \& Baroroh, 2016). Dengan menggunakan metode penelitian deskriptif akan lebih mudah menemukan deskripsi dan gambaran yang lebih mendalam tentang gejala sosial tertentu. Selain itu, metode ini akan membantu memberikan gambaran seutuhnya secara sistematik, faktual dan akurat dalam menjawab pertanyaan bagaimana inovasi pelayanan publik di Dinas Kependudukan dan Catatan Sipil Kota Bandung. Sumber data yang akan digunakan dalam penelitian ini 
adalah data sekunder. Pengumpulan data sekunder dilakukan dengan survei instansi untuk mendapatkan data-data dan telaah dokumen. Dengan situasi Indonesia yang sedang berada di tengah covid-19, kecil kemungkinan untuk menggunakan data primer karena adanya social distancing yang harus dipatuhi dari pemerintah. Jadi, penyusun hanya bisa menggunakan data sekunder dalam penelitian ini. Teknik analisis data yang digunakan oleh penyusun adalah deskriptif kualitatif. Data ini dilakukan dengan berbagai cara yang beragam. Analisis data selama proses pengumpulan data amat penting artinya bagi peneliti untuk melakukan pengamatan terfokus terhadap permasalahan yang dikaji. Analisis data dalam penelitian kualitatif pada dasarnya analisis deskriptif, diawali dengan pengelompokan data yang sama, selanjutnya dilakukan interpretasi untuk memberi makna setiap sub-aspek dan hubungan antara satu dengan lainnya. Kemudian, dilakukan analisis atau interpretasi keseluruhan aspek untuk memahami makna hubungan antara aspek yang satu dengan lainnya yang menjadi fokus penelitian. Makna diinterpretasi dalam penganalisaan data dari sudut pandang informan dimana penelitian tersebut dilaksanakan.

\section{PEMBAHASAN}

Berdasarkan hasil temuan penelitian, Dinas Kependudukan dan Pencatatan Sipil kota Bandung memiliki berbagai bentuk inovasi pelayanan publik. Relative Advantage (Keuntungan Relatif) inovasi yang dilakukan oleh pemerintah daerah harus dapat memberikan dampak yang positif. Pada atribut inovasi ini, keuntungan relatif yang perlu diukur untuk setiap inovasi adalah: manfaat ekonomis, kemudahan penggunaan, bekerja lebih cepat dan bekerja lebih mudah (Sehsa Cantika, Dewi Rostyaningsih, 2015). Penerapan inovasi pelayanan publik 
oleh Dinas Kependudukan dan Pencatatan Sipil Kota bandung adalah sebagai berikut :

\section{1. e-SPASI}

e-SPASI merupakan salah satu inovasi dari Dinas Kependudukan dan Catatan Sipil Kota Bandung yang mulai diterapkan pada tahun 2016. Pada awalnya pendaftaran penerbitan dokumen kependudukan dan pencatatan sipil dilakukan secara manual, hal ini menyebabkan menumpuknya masyarakat di kantor dinas tanpa bisa ditentukan atau tidak ada kepastian kapan dan jam berapa masyarakat akan dilayani. Situasi yang serba tidak nyaman ini memunculkan gagasan lalu terciptalah elektronik Sistem Pendaftaran Antrean Via SMS (e-SPASI) di kantor Dinas Kependudukan dan Catatan Sipil Kota Bandung.

Pitriyanti (2019) berpendapat bahwa layanan pembuatan dokumen kependudukan juga dapat dilakukan melalui elektronik Sistem Pendaftaran Antrean Via SMS (e-SPASI). Sistem dapat bekerja selama 24 jam, namun masih tetap terkontrol dengan sistem booking, sehingga tidak akan menumpuk daftar antrian yang terlalu banyak (melebihi kuota Dinas) dan masyarakat dapat datang sesaat sebelum waktunya mendapatkan pelayanan, sehingga masyarakat saat ini yang mengurus dokumen kependudukan di Disdukcapil terlihat rapi dan tidak berdesak-desakan lagi, serta menciptakan lingkungan yang nyaman dan tertib (Pitriyanti, 2019). Pada saat pandemi saat ini, inovasi tersebut tentu saja mendukung pencegahan penularan virus covid-19 karena dengan adanya inovasi tersebut tidak lagi terjadi kerumunan di kantor Disdukcapil Kota Bandung.

\section{Kartu Identitas Anak}

Salah satu bentuk kebijakan pemerintah dalam melindungi dan mensejahterakan masyarakat serta memantau penduduk tercantum pada kebijakan Kementerian Dalam Negeri (Kemendagri) yang 
mengeluarkan Peraturan Menteri Nomor 2 Tahun 2016 Tentang Kartu Identitas Anak (KIA) yang di muat dalam Undang-Undang Nomor 24 tahun 2013 Tentang Perubahan Atas Undang-Undang Nomor 23 Tahun 2006 Tentang Administrasi Kependudukan dibidang administrasi kependudukan. Kartu ini hanya diterbitkan oleh Dinas Kependudukan dan Pencatatan Sipil Kabupaten/Kota.

Kartu Identitas Anak (KIA) diberikan untuk anak 0-17 tahun kurang satu hari. Dengan diterbitkannya KIA diharapkan dapat memudahkan pendataan, perlindungan dan pelayanan publik serta sebagai upaya memberikan perlindungan dan realisasi hak konstitusional warga negara. Guna memaksimalkan manfaat KIA maka Disdukcapil Kota Bandung telah bekerja sama dengan lembaga-lembaga yang memberikan layanan kepada anak-anak, seperti bimbingan belajar, toko buku, restoran, tempat bermain anak, toko pakaian, waterpark, serta menyepakati bahwa anak/keluarga anak pemegang KIA akan mendapatkan diskon apabila melakukan transaksi dengan beberapa mitra yang disebutkan di atas.

\section{Ruang Bermain Anak}

Masyarakat yang berkunjung ke kantor Dinas Kependudukan dan Catatan Sipil tidak hanya kalangan orang dewasa, banyak juga diantaranya yang membawa anak-anak. Karena itulah ruang kosong yang berada di area kantor Disdukcapil Kota Bandung dimanfaatkan sebagai pojok bermain anak. Dalam area ini terdapat ayunan serta berbagai macam mainan untuk anak-anak. Area yang dibangun pada Juli 2017 ini membuat anak-anak senang bermain sembari menunggu selesainya proses pelayanan yang dilakukan (Dinas Kependudukan dan Catatan Sipil Kota Bandung, 2020).

\section{Ruang Laktasi}


Dinas Kependudukan dan Catatan Sipil Kota Bandung membangun ruangan khusus bagi ibu menyusui atau ruang laktasi pada Maret 2017. Ruangan ini akan memberikan kenyamanan untuk ibu yang membawa balitanya. Ketersediaan ruang laktasi ini merupakan salah satu bentuk kepedulian Disdukcapil Kota Bandung terhadap kaum Ibu, terlebih ASI (Air Susu Ibu) ekslusif merupakan hak anak yang harus diberikan ibu dengan kondisi nyaman serta aman.

\section{Pohon Harapan}

Dinas Kependudukan dan Catatan Sipil Kota Bandung sangat terbuka terhadap berbagai macam masukan, saran dan kritikan. Maka dari itu, pada Agustus 2017 dibuatlah Pohon Harapan dimana masyarakat yang telah selesai melakukan pelayanan akan diberikan secarik kertas untuk kemudian diminta menuliskan kesan kesannya terhadap pelayanan yang telah diberikan oleh petugas pelayanan. Komentar-komentar sera masukan - masukan yang dituliskan masyarakat tersebut diharapkan dapat dijadikan dasar bagi Disdukcapil untuk kedepannya dalam upaya melakukan penyempurnaan serta memberikan pelayanan terbaik kepada masyarakat.

\section{6. e-PunTEN}

Elektronik Pendaftaran Penduduk Non Permanen (e-PunTEN) merupakan terobosan untuk pelayanan adminstrasi kependudukan Disdukcapil Kota Bandung dalam bentuk aplikasi. Sebelumnya, penduduk pendatang yang belum pernah berada di Kota Bandung selama ini belum terdata. Oleh karena itu, pada September 2017 Dinas Kependudukan dan Catatan Sipil Kota Bandung merilis aplikasi ini, guna membangun dan menyusun database penduduk non permanen di Kota Bandung yang bisa dijadikan sebagai salah satu unsur dalam penyusunan perencanaan pembangunan di Kota Bandung di berbagai sektor. 
Dalam penyelenggaraan administrasi kependudukan, beberapa hal penting yang perlu dilakukan yaitu koordinasi penyelenggara, penataan teknis penyelenggara, pembinaan dan sosialisasi penyelenggaraan, pelaksanaan kegiatan pelayanan masyarakat, serta penyajian data kependudukan (Saputra, 2019). Salah satu kegiatan yang dilakukan oleh Dinas Kependudukan dan Pencatatan Sipil Kota Bandung daalam rangka mewujudkan administrasi kependudukan, yaitu dengan menyelenggarakan kegiatan sosialisasi tertib administrasi kependudukan dan pencatatan sipil, termasuk aplikasi e-PunTEN yang merupakan inovasi dari Dinas Kependudukan dan Pencatatan Sipil. Kemudian, faktor anggaran dan waktu juga melatarbelakangi terbentuknya aplikasi ini. Diharapkan melalui aplikasi ini anggaran yang dikeluarkan untuk pendataan penduduk non-permanen tidak terlalu besar. Pasalnya, jika mendata dari rumah ke rumah setiap hari akan memboroskan anggaran, misalnya untuk transportasi. Hal ini tentu saja tidak efektif dan efisien. Kemudian dari sisi waktu yang dibutuhkan Dinas Kependudukan dan Pencatatan Sipil untuk mengumpulkan datadata tersebut, hanya ada lima hari dalam seminggu. Artinya, hanya pada jam kerja saja para pejabat di Dinas Kependudukan dan Pencatatan Sipil dalam melakukan pendataannya. Sedangkan, jika menggunakan aplikasi secara online maka dapat dilakukan pendataan dimanapun dan kapanpun. Dengan dibentuknya aplikasi ini, diharapkan pendataan penduduk non-permanen hasilnya akan lebih maksimal (Dwiputra, 2019).

\section{Salaman}

SALAMAN merupakan inovasi yang dibuat Dinas Kependudukan dan Pencatatan Sipil (Disdukcapil) Kota Bandung untuk memberikan kemudahan bagi masyarakat dalam mengajukan dokumen kependudukan. Aplikasi tersebut dapat diakses melalui website resmi Disdukcapil Kota Bandung maupun diunduh melalui Play Store bagi 
pengguna Smartphone android. Aplikasi ini telah meraih penghargaan pada gelaran penghargaan Kompetisi Inovasi Jawa Barat (KIJB) tahun 2020 di Trans Luxury Hotel, Selasa (15 Desember 2020). Dalam mengakses aplikasi Salaman, masyarakat hanya perlu membuat akun dengan menggunakan Nomor Induk Keluarga (NIK) Kepala Keluarga, Nomor Kartu Keluarga (KK) terupdate serta e-mail dan nomor yang valid. Pada awal diluncurkan aplikasi Ini, 17 Desember 2018, Salaman merupakan salah satu opsi dalam pengajuan dokumen kependudukan disamping masih dibukanya layanan pengajuan secara offline. Namun, sejak pandemi Covid-19 merebak, layanan tatap muka di Disdukcapil Kota Bandung dihentikan dan dialihkan melalui layanan online. Salah satunya melalui Salaman yang meliputi:

\section{LayananAktaKelahiran;}

2. Akta Kematian

\section{Surat Keterangan Pindah WNI (SKPWNI)}

4. Pindah dalam Kota Bandung; dan

5. Kartu Identitas Anak (KIA).

Salah satu fitur istimewa dari Salaman adalah chatting. Fitur ini memungkinkan masyarakat berinteraksi langsung dengan operator terkait teknis pengajuan, persyaratan (Eldo \& Mutiarin, 2019), maupun kendala yang dihadapi dalam pengajuan dokumen. Dengan memanfaatkan fitur tersebut, diharapkan tidak akan ada lagi pengajuan dengan berkas yang kurang lengkap. Diaturnya formulir dan buku yang digunakan dalam administrasi kependudukan dalam Permendagri Nomor 109 tahun 2019, maka Salaman pun disesuaikan dengan peraturan tersebut. Permendagri Nomor 109 tahun 2019 memungkinkan masyarakat bisa dengan mudah melakukan pencetakan dokumen kependudukan secara mandiri, dan Salaman memfasilitasi hal tersebut. 
Masyarakat cukup duduk di rumah dan bersantai bersama keluarga, namun tetap bisa mengajukan dokumen kependudukan dan mencetaknya secara mandiri dengan kertas yang telah ditentukan yakni HVS ukuran A4 80 gram. Melalui aplikasi Salaman ini dapat memberikan manfaat yang sangat signifikan dengan adanya efisiensi dari segi biaya, waktu dan tenaga sehingga masyarakat tidak perlu repot bulak-balik ke kantor Disdukcapil Kota Bandung (Muharam, 2019). Tidak perlu mengeluarkan biaya transportasi, dan tidak perlu berkerumun di kantor Disdukcapil selama masa pandemi, karena layanan pengajuan dokumen kependudukan sudah bisa diakses dan selesai dalam genggaman.

\section{Bi EHa dan Mang Udin (Bisa Euy Hebat dan Mengga Urus Identitas Kependudukanna)}

Tahun 2016, Dinas Kependudukan dan Pencatatan Sipil Kota Bandung mulai melayani permohonan perekaman KTP elektronik ke rumah-rumah yang dikhususkan untuk orang sakit, disabilitas dan lansia yang tidak mampu melakukan perekaman ke kantor Disdukcapil, kecamatan atau lokasi-lokasi pelayanan lainnya. Saat itu pelayanan masih menggunakan alat perekaman portable serta mobil dinas pejabat untuk mencapai lokasi pemohon. Namun, seiring dengan semakin banyaknya permohonan perekaman KTP elektronik untuk orang sakit, disabilitas dan lansia, maka pada awal tahun 2018, Kepala Dinas kependudukan dan Pencatatan Sipil Kota Bandung bersama pejabat struktural di Lingkungan Disdukcapil Kota Bandung mulai mencari cara untuk menyiapkan sarana prasarana serta tim khusus untuk melayani perekaman ke rumah-rumah ini. Berbekal kreatifitas dan dana yang ada, 2 (dua) mobil pelayanan tidak berbasis IT yang awalnya hanya digunakan untuk sarana tambahan mobil pelayanan keliling (Mepeling) akhirnya disulap menjadi mobil pelayanan khusus perekaman KTP elektronik bagi orang sakit, disabilitas dan lansia. 80 Maka pada tanggal 
4 Oktober 2018, Wali Kota Bandung, Oded Daniel, meresmikan mobil pelayanan baru yang diberi nama Bi EHa (Bisa Euy Hebat) dan Mang Udin (Mengga Urus Identitas Kependudukanna). Diharapkan dengan adanya 2 mobil pelayanan khusus ini, hak warga Kota Bandung untuk mendapatkan dokumen kependudukan dapat terpenuhi

\section{Segitiga (Senam Gaya Tiga Menit)}

Senam segitiga adalah singkatan dari "SENAM GAYA TIGA MENIT" yang memiliki tujuan menghilangkan rasa bosan dan penat bagi pengunjung kegiatan ini bertujuan untuk melemaskan otot serta sendisendi dari para petugas front office sehingga sekalipun duduk seharian para petugas ini tetap sehat, selain itu senam segitiga juga dimaksudkan untuk menciptakan suasana keakraban antar petugas dan masyarakat pemohon dokumen Kependudukan dan Pencatatan Sipil. Senam ini juga memmiliki tujuan lain yaitu supaya menciptakan suasana di bagian front office agar terlihat lebih senang, gembira, dan akrab. Senam Segitiga dilakukan setiap hari 3 kali pada pagi hari setelah apel pagi, pukul 10 pagi, dan pukul 2 siang.

10. Geulis

Gerai Untuk Layanan Istimewa atau Geulis merupakan inovasi untuk memudahkan dan mendekatkan pelayanan kepada masyarakat. Geulis Merupakan Program Kolaborasi DPRD Kota Bandung dengan Dinas Kependudukan dan Pencatatan Sipil (Disukcapil), yang bertujuan untuk memudahkan masyarakat dalam membuat kartu identitas. Geulis pertama di Festival Citylink Malldiresmikan oleh Dirjen Kependudukan dan Catatan Sipil Kemendagri, Zudan Arif Fakrulloh, pada April 2018. Selanjutnya Geulis berada di BTC Fashion Mall (2019), Metro Indah Mall, dan DPRD Kota Bandung (2020). Untuk memudahkan pelayanan maka antrian layanan di Geulis menggunakan E-SPASI. Selain itu Geulis menerima beberapa pelayanan seperti perekaman dan 
pencetakan KTP, Kartu Identitas Anak, Akta Kelahiran dan juga Akta Kematian. Selain itu juga dapat konsultasi mengenai langkah-langkah syarat apa saja yang dibutuhkan untuk membuat suatu dokumen yang berkaitan dengan kependudukan.

\section{Adu Cepat}

Adu Cepat atau Pengaduan Untuk Cek Pemanfaatan Data merupakan aplikasi yang digunakan untuk menangani pengaduan tentang data kependudukan yang bermasalah di lembaga pengguna, serta untuk memantau evaluasi konektivitas jaringan dan laporan berkala. Adu Cepat merupakan sistem yang diterapkan di lembaga pengguna yang memanfaatkan data kependudukan pada layanan publik untuk mengatasi data kependudukan yang bermasalah. Sehingga masyarakat mendapatkan kepastian waktu untuk memperbaiki datanya. Aplikasi tersebut diluncurkan pada Februari 2020. Aplikasi Pemuda yang dapat diunduh melalui Playstore

\section{Pemuda}

Pemutakhiran data Mandiri atau Pemuda merupakan aplikasi berbasis web dan perangkat seluler yang dapat memutakhirkan data kependudukan secara mandiri. Aplikasi tersebut diluncurkan pada Februari 2020. Pemuda merupakan sistem layanan online yang menyediakan ruang akses bagi masyarakat dalam melakukan updating data penduduk secara mandiri berbasis website atau mobile. Di dalamnya, memuat form pemuktahiran elemen data kependudukan yang bersifat dinamis, mulai dari nama lengkap, jenis kelamin, agama, pendidikan, Jenis Kelamin, pekerjaan, golongan darah dan status perkawinan.

\section{Akta Kelahiran Braile}


Akta Kelahiran Braile dirilis pada Desember 2016. Akta Kelahiran Braile ini adalah salinan dari Akta Kelahiran yang berlaku secara nasional, namun dicetak serta diterjemahkan menggunakan huruf barile agar memudahkan kaum difabel mengetahui informasi Akta Kelahiran miliknya sendiri demi kemudahan dan juga kenyamanan mereka. Disdukcapil Kota Bandung bekerja sama dengan Panti Sosial Bina Netra (PSBN) Wyta Guna Bandung penulisan huruf braille. Akta bertuliskan braile ini wujud nyata dari negara hadir pada semua masyarakat, tidak hanya yang melek saja, tapi bagi yang tidak beruntung juga mendapat perlindungan negara. Merupakan hak warga negara Indonesia untuk melengkapi identitas diri dengan memiliki dokumen kependudukan. Pemkot Bandung melalui Dinas Kependudukan dan Catatan Sipil (Disdukcapil) memastikan akta kelahiran braille dapat diproses secara cepat dan gratis.

\section{Mepeling Akta Kelahiran}

Masyarakat Kota Bandung sangat membutuhkan layanan akta kelahiran, sementara hal lain untuk kapasitas di kantor Disdukcapil Kota Bandung terbatas. Sehingga dibuatlah inovasi layanan keliling yang disebut Mepeling. Mepeling adalah program pelayanan keliling (jemput bola) yang tujuannnya untuk mendekatkan layanan kepada masyarakat. Mepeling menggunakan mobil berbasis IT untuk pengoperasiaannya. Terdapat 6 mobil Mepeling yang diluncurkan pada April 2017.

Pada Peraturan Walikota Bandung Nomor 1338 Tahun 2014 menyelenggarakan fungsi kedua tentang Rincian Tugas Pokok, Fungsi, Uraian Tugas dan Tata Kerja Dinas Kependudukan dan Catatan Sipil Bandung, yaitu menyelenggarakan pelayanan pada bidang catatan sipil. Inovasi ini menggunakan dana dari APBD Kota Bandung dengan metode sosialisasi lebih banyak dilakukan di media sosial. Sistem inovasi ini bekerja sama dengan berbagai pihak contohnya pihak rumah sakit. Staff 
rumah sakit akan memberikan informasi kepada staff Dinas Kependudukan dan Catatan Sipil. Saat ada proses pengiriman staff Dinas Kependudukan dan Catatan Sipil akan segera menangani pengiriman akta kelahiran tersebut. Dengan begitu, saat ibu diperbolehkan pulang, bayi sudah memiliki akta kelahiran. Selain rumah sakit, mobil "jemput bola", Mepeling juga mengunjungi sekolah sekolah, tempat umum, dan kecamatan yang ada di Kota Bandung. Ini dirancang untuk mereka yang tidak bisa langsung pergi ke lokasi Dinas Kependudukan dan Catatan Sipil atau lokasi mobil Mepeling itu berada.

Mepeling Kota Bandung menyediakan layanan akhir pekan yang mana diberikan pada minggu pertama dan ketiga. Selanjutnya, terkait dengan mekanisme pembuatan akta kelahiran melalui mepeling yaitu pemohon bisa memperoleh informasi jadwal dari pelayanan mepeling melalui twitter@disdukcapil, instagram@DisdukcapilBdg, dan yang terakhir facebook DISDUKCAPIL Kota Bandung. Setelahnya, pengunjung atau pemohon dapat mengunjungi langsung ke lokasi dimana mobil Mepeling berada dan juga membawa pesyaratan yang diperlukan untuk proses pengajuan akta kelahiran.

Kelebihan dari Model Inovasi Mepeling Akta Kelahiran di Kota Bandung:

1. Pelayanan Mepeling (Jemput Bola) mendekatkan pelayanan kepada masyarakat

2. Masyarakat tidak perlu datang dan mengantri di kantor Dinas Kependudukan dan Catatan Sipil

3. Masyarakat cukup mengisi formulir permohonan, selanjutnya menyerahkan persyaratan yang ada kepada petugas Mepeling

4. Masyarakat dapat menentukan lokasi mana yang paling dijangkau untuk pembuatan akta kelahiran

5. Menghilangkan praktek percaloan. 
Kelemahan dari Model Inovasi Mepeling di Kota Bandung:

1. Sumber dana yang digunakan untuk kegiatan Mepeling berasal dari APBD

2. Waktu pelayanannya belum memiliki jadwal yang tetap sehingga membuat masyarakat sulit untuk mengetahui lokasi dimana mobil keliling

3. Sosialisasi inovasi mepeling lebih banyak dilakukan di sosial media, sedangkan tidak semua masyarakat Kota Bandung memiliki dan juga aktif dalam media sosial. Ini menyebabkan ketidaktahuan informasi mengenai inovasi mepeling.

4. Jumlah SDM yang bertugas melakukan pelayanan Mepeling "Jemput Bola" (keluar kantor) sebanyak 5 orang untuk satu mobil keliling. Dikarenakan petugas yang melakukan kegiatan mepeling juga merupakan petugas front office pada Disdukcapil Kota Bandung, sehingga pekerjaan yang ada di Kantor Dinas Kependudukan dan Catatan Sipil manjadi terhambat, seperti proses verifikasi dokumen yang menjadi persyaratan pembuatan akta kelahiran. Sehingga, Dinas Kependudukan dan Catatan Sipil belum berani melaksanakan kegiatan mepeling setiap hari.

5. Jumlah mobil keliling yang tersedia berjumlah 1 buah, sehingga pelayanan jemput bola yang dilakukan Dinas Kependudukan dan Catatan Sipil belum mampu menjaring seluruh wilayah Kota Bandung.

\section{Delivery Service Akta Kelahiran}

Delivery Service akta kelahiran pelayanan akta kelahiran yang inovatif diluncurkan oleh Dinas Kependudukan dan Catatan Sipil Kota Bandung pada 20 Mei 2016. Mulai diinovasikan oleh Walikota Bandung, Ridwan Kamil, secara langsung yang tujuannya untuk mempermudah masyarakat Kota Bandung mendapatkan Akta Kelahiran melalui jasa 
kurir akta kelahiran. Dengan menggunakan Delivery Service, akta kelahiran yang sudah diproses akan dikirim langsung ke alamat tujuan. Tahun 2016, pembiayaan jasa akta kelahiran ini menggunakan dana tanggung jawab sosial perusahaan (CSR) yang disediakan oleh Bank BJB dan PT.Pos. Selain dengan memberikan layanan pengiriman bantuan juga diberikan amplop tempat menyimpang akta kelahiran. Selain dilakukan dengan kurir bermotor juga bisa lewat pos. Untuk petugas yang menuliskan nama dan alamat tujuan belum ada, tetapi untuk petugas pengantar akta kelahiran itu adalah petugas PT Pos yang mengantarkan surat - surat.

Inovasi Delivery Service dilaksanakan untuk mempermudah masyarakat Kota Bandung memiliki akta kelahiran. Adanya Delivery Service ini masyarakat Kota Bandung tidak perlu datang dan mengantri di kantor Dinas Kependudukan dan Catatan Sipil untuk mengambil akta kelahiran yang telah selesai di proses. Selanjutnya, biaya untuk pengiriman akta kelahiran ini juga gratis dan tujuan dari adanya Delivery Service ini adalah menghilangkan praktek percaloan.

Kelemahan dari inovasi ini terdapat petugas yang tidak ada untuk menuliskan kembali alamat yang ditulis pemohon. Ini menyebabkan formulir yang sudah ditulis oleh pemohon langsung ditempelkan pada amplop pengiriman. Selanjutnya, adanya kendala dari PT Pos membuat pengiriman yang menjadi lambat. Pihak Dinas Kependudukan dan Catatan Sipil harus selalu melakukan koordinasi dengan PT Pos, guna membahas permasalahan yang terjadi dalam pengiriman akta kelahiran. Selain itu, tingkat kepercayaan masyarakat pemohon pembuatan akta kelahiran masih rendah disebabkan oleh sebagian warganya menolak untuk diantarkan langsung kerumah karena bisa saja dirumah tidak ada seseorang. Hal ini menyebabkan presentase pengguna inovasi ini sangat rendah. 


\section{KESIMPULAN}

Berdasarkan uraian pada bab-bab sebelumnya, maka penulis memberikan kesimpulan bahwa inovasi pelayanan publik di Dinas Kependudukan dan Pencatatan Sipil Kota Bandung memberikan banyak keuntungan dan juga manfaat bagi masyarakat Kota Bandung. Dilihat dari berbagai macam inovasi pelayanan publik di Dinas Kependudukan dan Pencatatan Sipil Kota Bandung, yang paling banyak memberikan manfaat bagi masyarakat adalah e-SPASI karena sistem dapat bekerja selama 24 jam, namun masih tetap terkontrol dengan sistem booking, sehingga tidak akan menumpuk daftar antrian yang terlalu banyak (melebihi kuota Dinas) dan masyarakat dapat datang sesaat sebelum waktunya mendapatkan pelayanan, sehingga masyarakat saat ini yang mengurus dokumen kependudukan di Disdukcapil terlihat rapi dan tidak berdesak-desakan lagi, serta menciptakan lingkungan yang nyaman dan tertib. Inovasi e-SPASI telah teruji dan terbukti mempunyai keuntungan atau nilai lebih dibandingkan dengan inovasi yang lainnya. Apalagi disaat pandemi seperti ini, maka manfaat dari inovasi pelayanan e-SPASI ini dapat berguna bagi masyarakat Kota Bandung.

\section{DAFTAR PUSTAKA}

Dinas Kependudukan dan Catatan Sipil Kota Bandung. (2020). Inovasi Pelayanan di Dinas Kependudukan dan Catatan Sipil Kota Bandung. Retrieved from disdukcapil.bandung.go.id website: https://disdukcapil.bandung.go.id/

Dwiputra, S. N. (2019). Bentuk pelayanan e-punten dalam meningkatkan kesadaran pendatang untuk memiliki surat keterangan tinggal sementara (skts). 
Eldo, D. H. A. P., \& Mutiarin, D. (2019). Analisis Best Practice Inovasi Pelayanan Publik (Studi pada Inovasi Pelayanan "Kumis MbahTejo" di Kecamatan Tegalrejo Kota Yogyakarta). Jurnal Manajemen Pelayanan Publik, 1(2), 156. https://doi.org/10.24198/jmpp.v1i2.16753

Fikri, A. A. H. S., Sholeh, M., \& Baroroh, K. (2016). Fenomena Kemiskinan Perkotaan (Urban Poverty) Di Yogyakarta: Suatu Kajian Struktur Dan Respons Kebijakan. Jurnal UNY, 1-15. Retrieved from http://eprints.uny.ac.id/30973/1/Artikel Urban Poverty Dikti Aula dkk FE.pdf.

Haqie, Z. A., Nadiah, R. E., \& Ariyani, O. P. (2020). Inovasi Pelayanan Publik Suroboyo Bis Di Kota Surabaya. JPSI (Journal of Public Sector Innovations), 5(1), 23. https://doi.org/10.26740/jpsi.v5n1.p23-30

Jati, W. R. (2011). Inovasi Pelayanan Publik Setengah Hati: Studi Pelayanan Publik di SAMSAT Kota Yogyakarta. JSP: Jurnal Ilmu Sosial Dan Ilmu Politik, 15(1), 68-78. https://doi.org/10.22146/jsp.10926

Muharam, R. S. (2019). Inovasi Pelayanan Publik Dalam Menghadapi Era Revolusi Industri 4.0 Di Kota Bandung. Decision: Jurnal Administrasi Publik, 1(01), 39. https://doi.org/10.23969/decision.v1i01.1401

Nasikhah, M. A. (2019). Inovasi Pelayanan Transportasi Publik Berbasis Teknologi Informasi. Jurnal Inovasi Ilmu Sosial Dan Politik, 1(1), 26. https://doi.org/10.33474/jisop.v1i1.2670

Sehsa Cantika, Dewi Rostyaningsih, T. D. (2015). Analisis Pelaksanaan Inovasi Pelayanan Publik Padakantor Pertanahan Kota Semarang. Journal of Public Policy and Management Review, 4(4), 267-279.

Yanuar, R. M. (2019). Inovasi Pelayanan Publik (Studi Kasus: Public Safety Center (PSC) 119 Kabupaten Bantul Sebagai Layanan Kesehatan dan Kegawatdaruratan). Jurnal Ilmu Pemerintahan, 4(1), 1-20. Retrieved from https://ojs.umrah.ac.id/index.php/kemudi/article/view/1335 
Arista, W. D., \& Suderana, W. (2019). Implementasi Kebijakan Program Kartu Identitas Anak (Kia) Di Dinas Kependudukan Dan Catatan Sipil Kabupaten Badung. Jurnal Ilmiah Dinamika Sosial, 3(1), 56. https://doi.org/10.38043/jids.v3i1.1733

Hamdam, H., Ibrahim, A., \& ... (2020). Inovasi Pelayanan Publik Melalui Up3Sk Di Dinas Kependudukan Dan Pencatatan Sipil Kabupaten Pinrang. ... Administrasi Publik, 6. Retrieved from https://journal.unismuh.ac.id/index.php/kolaborasi/article/view/4046

Pitriyanti, D. (2018). Kepemimpinan Ridwan Kamil Di Kota Bandung Tahun 2013-2018 : Kajian Inovasi Kebijakan Kepemimpinan Adaptif. Journal of Politic and Government Studies, 8(2), 101-110.

Saputra, W. G. (2019). Kualitas Pelayanan Sistem E-Punten di Kota Bandung. Universitas Komputer Indonesia.

Sururi, A. (2019). Inovasi Kebijakan Publik. Journal of Chemical Information and Modeling, 53(9), 1689-1699.

Iv, B. A. B., Penelitian, H., \& Pembahasan, D. A. N. (2019). ) Berdasarkan Gabar di atas Kota Bandung terletak di wilayah Jawa Barat dan merupakan Ibukota Provinsi Jawa Barat.Kota Bandung secara geografis 59. 59-133.

Rejeki, P. W., \& Susanty, Y. (2017). Pengembangan Model Inovasi Delivery Service Akta Kelahiran Di Kota Bandung. Jurnal Ilmu Administrasi: Media Pengembangan Ilmu Dan Praktek Administrasi, 14(1), 139-151. https://doi.org/10.31113/jia.v14i1.7

Wulandari, P., \& Susanty, Y. (2018). Strategi Pengembangan Model Inovasi "Mepeling” Akta Kelahiran di Kota Bandung. Jurnal Wacana Kinerja: Kajian Praktis-Akademis Kinerja Dan Administrasi Pelayanan Publik, 20(1), 15. https://doi.org/10.31845/jwk.v20i1.120 
Ilmupemerintahan, K., Volume, P. D., Sa, A., Sadat, A., Buton, M., No, J. B., Baubau, K., Tenggara, S., Studi, P., Pemerintahan, I., Ilmu, F., Dan, S., \& Politik, I. (2019). Jurnal ilmu pemerintahan: 4(April), 29-38.

Kurniasih, L. W., \& Widowati, N. (2016). Pelayanan Publik Dalam Menciptakan Pelayanan Prima Di Dinas Kependudukan Dan Pencatatan Sipil Kabupaten Pemalang. Indonesian Journal of Public Policy and Management Review. https://www.neliti.com/id/publications/100659/pelayananpublik-dalam-menciptakan-pelayanan-prima-di-dinas-kependudukan-danpen

Mansyur, S. (2013). Efektifitas Pelayanan Publik Dalam Perspektif Konsep Administrasi Publik. Jurnal Academica FISIP Untad, 05, 965-972.

Pananrangim, A. (2019). Inovasi Peningkatan Kualitas Pelayanan Publik Melalui Citizen 's Charter. Meraja Kournal, 2(2), 119-134.

Papua, U. Y. (2011). KEPENDUDUKAN DAN CATATAN SIPIL KABUPATEN Agus Sofyan. 1-13.

Sahuri, C., \& Aspalinda, M. (2014). Pelayanan Publik Pada Dinas Kependudukan Dan Catatan Sipil Kabupaten Karimun ( Studi Kasus Pada Pelayanan Akta Kelahiran). Jurnal Online Mahasiswa Fakultas Ilmu Sosial Dan Ilmu Politik Universitas Riau, 1(1).

Tetap, D., Ilmu, F., Politik, I., Islam, U., Utara, S., Publik, I. A., \& Bandung, U. P. (2009). Dosen Tetap Fakultas Ilmu Sosial dan Ilmu Politik Universitas Islam Sumatera Utara. Sedang menempuh studi doktor (S3) bidang Ilmu Administrasi Publik di Universitas Padjadjaran Bandung. 